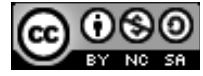

https://doi.org/10.31743/abmk.13185

TOMASZ NOWICKI* - LUBLIN

\title{
SPUŚCIZNA FOTOGRAFICZNA KS. PROF. TADEUSZA STYCZNIA SDS W ZASOBIE ARCHIWUM INSTYTUTU JANA PAWLA II - STAN UPORZĄDKOWANIA
}

\begin{abstract}
Streszczenie
W Archiwum Instytutu Jana Pawła II przechowywana jest spuścizna archiwalna po ks. profesorze Tadeuszu Styczniu, uczniu Karola Wojtyły, długoletnim dyrektorze Instytutu Jana Pawła II. Materiały archiwalne wchodzące w skład spuścizny, obok opracowanej już dokumentacji aktowej, tworzą także liczne obiekty występujące w różnych postaciach i formach fotograficznego zapisu obrazu. Najliczniej występują odbitki pozytywowe, ale przechowywane są także negatywy i obrazowa dokumentacja zapisana cyfrowo. Autor omawia stan uporządkowania tego zbioru przez pryzmat metodyki archiwalnej, wskazuje na ważniejsze serie i tematy fotograficzne, szczególnie przedstawiając te, które zawierają fotografie związane z działalnością na KUL Karola Wojtyły, a potem papieża Jana Pawła II. Zwraca uwagę na te serie dokumentacji fotograficznej, które ukazują wyjątkowe relacje przyjaźni między papieżem a twórcą spuścizny, ks. Tadeuszem Styczniem. Podsumowując określa konieczne kolejne etapy archiwalnego opracowania i zwraca uwagę na konieczność szybkiego uporządkowania, a szczególnie opisania serii tematycznych oraz identyfikacji wydarzeń i osób przedstawionych na pojedynczych fotografiach.

Słowa kluczowe: spuścizna archiwalna; ks. Tadeusz Styczeń; Instytut Badań nad Myślą Jana Pawła II KUL; Instytut Jana Pawła II KUL; zbiory fotograficzne
\end{abstract}

* Tomasz Nowicki - dr hab. nauk humanistycznych w zakresie historii, prof. KUL, Instytut Historii, Katolicki Uniwersytet Lubelski Jana Pawła II

e-mail: tomasz.nowicki@kul.pl

https://orcid.org/0000-0003-1185-9358 


\section{Wprowadzenie}

Niemal odwiecznym pragnieniem człowieka jest chęć zatrzymania w pamięci przeżytego wydarzenia, spotkania z innymi ludźmi, ważnej i wyjątkowej uroczystości czy postaci. Do momentu opracowania techniki fotograficznej było to możliwe tylko w ludzkiej pamięci, w dziele artysty lub w postaci pisemnego opisu zdarzeń. Dopiero kiedy w 1826 r. francuski fizyk Joseph Nicéphore Niépce po raz pierwszy stosując techniki naświetlania, wykonał obraz znany współcześnie jako Widok z okna Le Gras, a następnie gdy w 1839 r. Louis Jacques Daguerre opracował technikę dagerotypii, ludzie otrzymali możliwość utrwalania zdarzeń. Rozwój technik fotograficznych stopniowo upowszechniał fotografię, a jednocześnie coraz bardziej ułatwiał wykonywanie zdjęć. Dzisiaj, w dobie fotografii cyfrowej, czynność fotografowania jest dostępna dla każdego posiadającego telefon komórkowy. Odkrycie z pierwszej ćwierci XIX wieku dało możliwości utrwalenia chwili i uchwycenia obrazu, pozwalając umieścić go niejako poza czasem. Fotografia utrwaliła więc minioną teraźniejszość, przechowując w obrazie przeszłość ${ }^{1}$.

Z perspektywy opracowania archiwalnego powstaje wszakże pytanie, co należy rozumieć pod terminem fotografia. Jak wyjaśniają w punkcie I.2. Wskazówki metodyczne dotyczace zasad opracowania fotografii $w$ archiwach państwowych, będące załącznikiem do Decyzji Nr 8 Naczelnego Dyrektora Archiwów Państwowych z dnia 24 kwietnia 2006 r. $^{2}$, za fotografię uznaje się ,,wszelkie statyczne formy fotograficznego zapisu obrazu, niezależnie od techniki wykonania". Dalej czytamy, że reprodukcje np. akt, dokumentacji kartograficznej, technicznej, pieczęci, czy to w formie mikrofilmu, czy też fotokopii, nie wchodzą do zasobu fotografii. Warto w tym miejscu przytoczyć jeszcze jedno wyjaśnienie. Zbyt często bowiem, mówiąc o fotografii, mamy na myśli tylko jej postać pozytywową. Tymczasem wspomniane wytyczne wyraźnie stwierdzają, że egzemplarzem archiwalnym fotografii jest nośnik pierwotny z zapisem fotografii (dla obiektów powstałych w wyniku chemicznej obróbki materiału światłoczułego) lub wzorcowy plik danych, niezmieniony w stosunku do pierwotnego zapisu (dla zapisu cyfrowego) ${ }^{3}$. Dopiero w sytuacji, gdy nie zachował się nośnik z pierwotnym zapisem fotografii lub wzorcowy plik danych, za egzemplarz archiwalny uznaje się kopię analogową lub plik danych zastępczo uznany za wzorcowy ${ }^{4}$.

Niezależnie od formy obiektu fotograficznego uznanego za materiał archiwalny trzeba przyznać, że fotografia ukazująca przeszłość i dokładnie utrwalająca minioną chwilę sprawia, że ten typ archiwaliów należy do jednych z najciekawszych rodzajów dokumentacji archiwalnej. Nie inaczej jest w przypadku obiektów fotograficznych zebranych w prywatnych zbiorach archiwalnych, a zwłaszcza w spu-

${ }^{1}$ Zob. M. Tarsa, Czas - pamięć - fotografia. Próba fenomenologicznej refleksji nad fotografia, „Estetyka i Krytyka”, 7/8 (2/2004-1/2005) s. 170-172.

${ }^{2}$ Zob. Akty normatywne Naczelnego Dyrektora Archiwów Państwowych, rok 2006, https:// www.archiwa.gov.pl/pl/zarzadzanie-dokumentacja/prawo-archiwalne/akty-normatywne-naczelnego-dyrektora-archiw\%C3\%B3w-pa\%C5\%84stwowych\# (dostęp: 28.10. 2021)

${ }^{3}$ Tamże, pkt. I.4.

${ }^{4}$ Tamże, pkt. I.5. 
ściznach osób znanych, mających szerokie kontakty i uczestniczących w ważnych wydarzeniach. Fotograficzne utrwalenie tych zdarzeń i osób jest niezwykle cenne z punktu widzenia archiwisty. Stąd celem niniejszego artykułu jest przede wszystkim ukazanie pierwszego etapu prac nad dokumentacją fotograficzną znajdującą się w Archiwum Instytutu Jana Pawła II.

\section{Autor spuścizny}

Do zespołów, których wartość archiwalna jest wyjątkowa, należą bez wątpienia spuścizny po naukowcach. Jedną z nich jest przechowywane w Instytucie Jana Pawła II KUL spuścizna po ks. profesorze Tadeuszu Styczniu. Sam Instytut Badań nad Myślą Jana Pawła II powstał w 1982 r. Do jego zadań od początku istnienia należało prowadzenia studiów nad myślą i dziełem papieża Jana Pawła II, a jego pierwszym dyrektorem został właśnie ks. T. Styczeń, uczeń i bezpośredni następca Karola Wojtyły - Jana Pawła II w Katedrze Etyki na Wydziale Filozofii KUL. To właśnie z jego działalnością badawczą związany jest przede wszystkim obecny zasób Instytutu.

Ks. T. Styczeń należy do jednych z najwybitniejszych polskich etyków. Członek zgromadzenia salwatorianów, pod kierunkiem przyszłego arcybiskupa krakowskiego i papieża napisał pracę magisterską oraz obronił doktorat. Na KUL rozpoczął pracę w 1957 r. w Katedrze Etyki KUL. W 1970 r. uzyskał habilitację. Na posiedzeniu w dniu 12 grudnia 1979 r. Senat KUL zdecydował o powołaniu ks. T. Stycznia na stanowisko kierownika Katedry Etyki KUL. Funkcję tę pełnił nieprzerwanie do 2002 r., kiedy przeszedł na emeryturę. Jednak do 2007 r. prowadził jeszcze zajęcia ze studentami. Do tegoż roku był także dyrektorem Instytutu Jana Pawła II KUL (w latach 1982-2007), a zarazem redaktorem naczelnym kwartalnika „Ethos”. Jego działalność naukowa, dydaktyczna i organizacyjna wykraczała poza uniwersytet. Przez wiele lat wykładał etykę w Wyższym Seminarium Duchownym Księży Salwatorianów w Bagnie Śląskim koło Trzebnicy. W latach 1981-1986 wykładał w Pontificio Istituto Giovanni Paolo II per Studi sul Matrimonio e Famiglia (Instytut Jana Pawła II Studiów nad Małżeństwem i Rodziną) Papieskiego Uniwersytetu Laterańskiego w Rzymie. Był konsultorem Papieskiej Rady do spraw Rodziny oraz Papieskiej Rady do spraw Duszpasterstwa Służby Zdrowia, a także członkiem zwyczajnym Papieskiej Akademii Życia, a przez 10 lat także członkiem Rady Zarządzającej tej Akademii. Należał do licznych towarzystw naukowych, tak krajowych, jak zagranicznych, m.in. w 1981 r. zakładał wspólnie z prof. Josefem Seifertem Międzynarodową Akademię Filozofii z siedzibą początkowo w Irving w stanie Teksas , a później w Księstwie Liechtenstein (od 1986).

Jest autorem ponad 300 prac z zakresu etyki, metaetyki i antropologii, w tym ponad 20 książek. Był redaktorem (lub współredaktorem) wielu publikacji związanych z myślą Jana Pawła II, w tym kilkunastu książek w większości publikowanych 
w ramach serii: „Jan Paweł II naucza”. Zmarł po ciężkiej chorobie w dniu 14 października 2010 r. w Trzebnicy.

Wszystkie te aktywności ks. T. Stycznia były przez niego świadomie dokumentowane i zbierane. Na maszynopisie jednego ze swoich tekstów własnoręcznie napisał szczególną notatkę: „Nie niszczyć! Są tu cenne rzeczy, które skreśliłem, by skrócić". Swiadczy to o wyjątkowym zrozumieniu wartości nawet takich materiałów, które zawierają liczne poprawki, skreślenia, uwagi i adnotacje. A warto zaznaczyć, że ks. T. Styczeń wielokrotnie poprawiał i zmieniał swoje teksty, zachowując niekiedy kilkanaście wersji tego samego artykułu czy wystąpienia. Oczywiście spuściznę duchownego tworzy przede wszystkim dokumentacja aktowa. Została ona już uporządkowana i opracowana. Składa się z 741 jednostek podzielonych na 17 serii tematycznych, jak np. seria materiałów dotyczących publikacji naukowych, wystąpień i tekstów niepublikowanych, materiałów dotyczących działalności dydaktycznej, społecznej, wydawniczej i redakcyjnej. Osobne grupy akt tworzą serie dotyczące materiałów osobistych, biograficznych, gospodarczych czy majątkowych ${ }^{6}$.

\section{Fotografie w części aktowej spuścizny}

Już w tej aktowej części spuścizny spotkać można dokumentację fotograficzną, przede wszystkim wśród serii dotyczącej korespondencji otrzymywanej przez ks. T. Stycznia. Są tutaj np. cenne materiały fotograficzne w postaci odbitek pozytywowych, które otrzymywał wraz z listami. Wśród tej dokumentacji zwraca szczególną uwagę korespondencja z rodziną książęcą z Liechtensteinu, z którą ks. Stycznia łączyła bliska przyjaźń i u której często był gościem. Niejednokrotnie przy okazji przesyłanych życzeń świątecznych otrzymywał wklejone fotografie portretowe, zwłaszcza rodziny następcy tronu księcia Alojzego, jego małżonki Zofii oraz ich dzieci Józefa Wacława, Marii Karoliny, Jerzego i Mikołaja ${ }^{7}$.

${ }^{5}$ Zob. E. Podrez, Ksiądz Tadeusz Styczeń, w: Człowiek, byt, wartość. Antropologiczne i metafizyczne podstawy aksjologii chrześcijańskiej, Warszawa 1989, s. 48-59; T. Ślipko, Ksiądz Tadeusz Styczeń, w: Polska filozofia powojenna, Warszawa 2001, s. 257-272; W. Chudy, Ksiadz Tadeusz Styczeń - ambasador republiki sumienia, „Ethos”, 15 (2002), z. 1-2, s. 297-303; A. Szostek, Styczeń Tadeusz, w: Powszechna encyklopedia filozofii, t. 10, red. A. Maryniarczyk, Lublin 2009, s. 408411; tenże, Styczeń Tadeusz SDS, w: Encyklopedia 100-lecia KUL, t. 2, red. E. Gigilewicz, Lublin 2018, s. 411-412; R. Moń, S. Tondel, J. Krokos, A. Waleszczyński, Tadeusz Styczeń, Kraków 2019. O Międzynarodowej Akademii Filozofii zob. J. F. Jacko, Rozmowa z profesorem Josefem Seifertem, rektorem Międzynarodowej Akademii Filozofii w Księstwie Liechtenstein, „Roczniki Filozoficzne”, 43-44 (1996), nr 2, s. 229-233.

${ }^{6}$ Dla aktowej części spuścizny został już przygotowany inwentarz archiwalny: T. Nowicki, G. Misiura, Spuścizna archiwalna Księdza Profesora Tadeusza Stycznia SDS - inwentarz, cz. 1: Dokumentacja aktowa, Lublin 2021. Por. T. Nowicki, G. Misiura, K. Perzyna, Spuścizna archiwalna po Ks. Profesorze Tadeuszu Styczniu SDS (1932-2010) jako przyktad archiwum prywatnego po wybitnym uczonym, „Archiva Ecclesiastica” 10 (2017), s. 13-23.

${ }^{7}$ Archiwum Instytutu Jana Pawła II KUL, Spuścizna archiwalna Księdza Profesora Tadeusza Stycznia SDS (dalej Archiwum...), sygn. 452 (Korespondencja: Liechtenstein - rodzina książęca). Pojedyncze obiekty fotograficzne w postaci kopii pozytywowych są w jednostkach o sygn. 400/3 (Ochrona życia poczętego, cz. 3), 457 (Korespondencja: Paczkowie Renata i Józef - Pieper Josef), 


\section{Zbiór fotografii}

Fotografie w postaci kopii pozytywowych pojawiają się jednak dość sporadycznie wśród dokumentacji aktowej i stanowią drobną tylko część materiałów fotograficznych, które ks. T. Styczeń pozostawił w swojej spuściźnie. Zdecydowana większość zbiorów fotograficznych zarchiwizowała się jako osobna, wyodrębniona część spuścizny. Prace nad jej uporządkowaniem zaczęły się dopiero niedawno, w związku z tym są na razie na bardzo wczesnym etapie opracowania. Zbiór ten był pierwotnie zebrany w kilku tekturowych pudłach i plastykowych reklamówkach.

Zanim jednak zostaną dokładniej omówione już rozpoznane materiały fotograficzne znajdujące się w zasobie Instytutu Jana Pawła II KUL, należy przedstawić obecny stan zaawansowania prac porządkowych ${ }^{8}$. Przystępując zatem do opracowywania dokumentacji fotograficznej w spuściźnie ks. T. Stycznia, od razu na początku, po wstępnym zapoznaniu się ze stanem zbioru, można było zauważyć, że materiały fotograficzne nie zostały ułożone przez twórcę według jakiegoś klucza. Nie miały one w zasadzie oryginalnego układu, który mógłby być podstawą do dalszych prac. Wykonane zostały przez wielu różnych fotografów, zwłaszcza tych związanych z KUL, jak też autorów watykańskich, ale także przez wiele innych osób, które przekazały ks. T. Styczniowi swoje fotografie. Nie ma na razie podstaw, by stwierdzić, że autorem fotografii był on sam.

Zbiory fotograficzne zgromadzone przez ks. T. Stycznia to przede wszystkim bardzo liczne odbitki pozytywowe tak czarno-białe, jak również kolorowe. Pojawiają się również w spuściźnie filmy negatywowe oraz slajdy pozytywowe. Ten typ fotografii wymaga jednak odpowiednich narzędzi uzbrajających oko, stąd prace nad tą odmianą dokumentacji fotograficznej zostaną podjęte po wstępnym rozeznaniu kopii pozytywowych, których ogląd nie wymaga dodatkowego i specjalistycznego oprzyrządowania. Na obecnym etapie zaawansowania prac widać już jednak, że część negatywów będzie można z łatwością połączyć z kopiami pozytywowymi, gdyż zachowały się one wspólnie w kopertach z zakładów fotograficznych.

Nie oznacza to bynajmniej, że prace nad pozytywami są proste i łatwe. Wynika to z kilku istotnych dla opracowania przyczyn. Po pierwsze, o czym już wspomniano, kopie pozytywowe, które stanowią największą grupę obiektów w spuściźnie, nie były zazwyczaj ułożone przez twórcę, nie miały jakiegoś trwałego, nadanego przez niego układu. Ksiądz T. Styczeń nie pogrupował ich w albumach, segregatorach. Zwykle fotografie były przechowywane zbiorczo w kopertach lub innych opakowaniach, czasami w takich, które otrzymał z zakładu fotograficznego po wywołaniu. Najczęściej brak było jakichś opisów, które mogłyby precyzować

465 (Korespondencja: V-W), 466/1 (Korespondencja: Watykan, cz. 1) i 466/2 (Korespondencja: Watykan, cz. 2).

${ }^{8} \mathrm{Na}$ temat opracowania fotografii zob. Metodyka pracy archiwalnej, red. S. Nawrocki, S. Sierpowski, Poznań 1998, wyd. 3 zmienione i poszerzone, s. 196-200, a także H. Robótka, Opracowanie i opis archiwaliów, Toruń 2010, s. 103 oraz wspomniane wcześniej wskazówki metodyczne dotyczące zasad opracowania fotografii w archiwach państwowych wprowadzone w 2006 r. Decyzją nr 8 Naczelnego Dyrektora Archiwów Państwowych (zob. przypis nr 2). 
chronologię, tematykę sfotografowanego wydarzenia czy też osoby ujęte na zdjęciu. Nawet jeśli takie informacje się pojawiały, to były nader sporadyczne, zwykle opisane na odwrocie niektórych fotografii.

Po drugie od razu można było zauważyć, że niektóre grupy fotografii w kopertach były przemieszane. Niekiedy tworzyły serie tematyczne, lecz te układy bywały zaburzone poprzez fotografie, których nie można było zaliczyć do tych serii, gdyż pochodziły z całkowicie innych tematycznie cykli.

Istotnym problemem utrudniającym łączenie fotografii $\mathrm{w}$ serie jest fakt, że wiele wydarzeń utrwalonych na nośnikach fotograficznych miało podobny charakter. Pojawiają się $n p$. serie $\mathrm{z}$ wielu różnych sympozjów organizowanych przez Instytut Jana Pawła II, zazwyczaj w tym samym miejscu (np. w Auli im. Stefana Kardynała Wyszyńskiego, w kościele akademickim, w sali Instytutu Jana Pawła II). W sytuacji braku opisu na fotografii lub na kopercie, a także braku możliwości identyfikacji na podstawie samej fotografii, nie zawsze jest możliwe doprecyzowanie i dokładne rozeznanie, przynajmniej na obecnym etapie porządkowania, jakie spotkanie zostało zobrazowane. Inną jeszcze niedogodnością są pojawiające się nieoczekiwanie wśród różnych serii fotografii wielokrotne kopie tych samych ujęć, niekiedy o innych formatach.

Opracowanie zatem całego zbioru fotograficznego wchodzącego w skład spuścizny ks. T. Stycznia i zgromadzonej w Archiwum Instytutu Jana Pawła II wymaga znajomości całości zasobu, nie tylko zresztą fotograficznego, i wracania niekiedy do serii ujęć i tematów, które wydawały się już pełne i zamknięte.

\section{Serie tematyczne fotografii w spuściźnie}

Jak wcześniej wspomniano, na początku najłatwiej uporządkować odbitki pozytywowe. Na tym etapie nie określa się jeszcze, czy wszystkie pozytywy zaliczają się do egzemplarzy archiwalnych. W pierwszej kolejności czynności zmierzają do usystematyzowania i wyodrębnienia głównych serii tematycznych, przypisując do nich fotografie. Obecnie zdołano ustalić 120 takich serii. Nie można jednak w tej chwili przyjąć, że są to już jednostki archiwalne. Być może tak się stanie i wyodrębnione już serie będą odpowiadały jednostkom, ale być może pełne rozeznanie materiału fotograficznego narzuci nieco inną strukturę tego zbioru.

Odbitki pozytywowe przyporządkowane do serii tematycznych obrazują wydarzenia od lat 60. XX wieku do pierwszego dziesięciolecia XXI wieku. Liczba pojedynczych fotografii w postaci kopii pozytywowych włączonych do serii przyjętych w trakcie wstępnego porządkowania wynosi obecnie niemal 2800 obiektów. Można już teraz przewidywać, że ostateczna liczba obiektów fotograficznych w postaci odbitek pozytywowych wyniesie być może nawet 5000 sztuk. Będzie to jednak dokładnie wiadome dopiero po ostatecznym zakończeniu opracowania. Do tego będzie trzeba wliczyć najpewniej kilkanaście serii fotografii w formie negatywów (które zapewne będą materiałem pierwotnym dla części kopii pozytywowych) oraz niewielką liczbę slajdów. Również w materiałach cyfrowych (dyskietkach, płytach CD czy dyskach komputerowych), które też wchodzą w skład spuścizny ks. T. Stycznia, znajduje się dokumentacja obrazowa, zatem także po- 
winna być ostatecznie włączona do inwentarza archiwalnego obejmującego materiały fotograficzne.

Dotychczas przeprowadzone prace porządkowe pozwalają na wyodrębnienie roboczych serii tematycznych. Poniżej przedstawione zostaną te, które już teraz zaliczyć można do najważniejszych i najcenniejszych. Za takie można uznać zwłaszcza te grupy fotografii, które odnoszą się do patrona instytutu, czyli Karola Wojtyły - Jana Pawła II. W omawianym zasobie spotykamy zatem serie dotyczące wydarzeń związanych z jego pracą na KUL. Do najstarszych należą np. seria fotografii z wykładów dla duchowieństwa z 1964 r. ${ }^{9}$ :

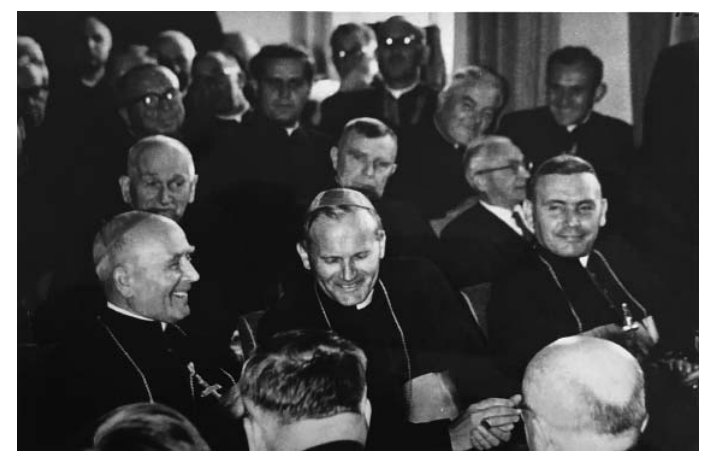

seria $\mathrm{z}$ uroczystości milenijnych obchodzonych na uniwersytecie $\mathrm{w}$ dniach 5-6 VI $1966 \mathrm{rr}^{10}$ :
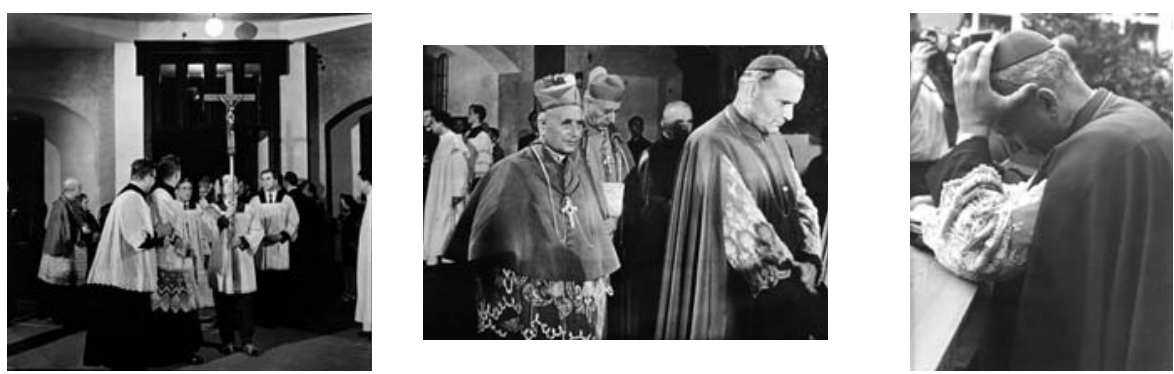

${ }^{9}$ Archiwum..., Zbiór fotografii, seria Karol Wojtyła na KUL - wykłady dla duchowieństwa, sierpień 1964 r., fot. M. Hałasa. Na fotografii ks. abp Karol Wojtyła w otoczeniu biskupów podczas wykładu.

${ }^{10}$ Archiwum..., Zbiór fotografii, seria Karol Wojtyła na KUL - uroczystości milenijne na KUL, 5-6 VI 1966 r., fot. M. Hałasa. Fot. 1: procesja liturgiczna wchodząca do Kościoła Akademickiego KUL; fot. 2: procesja liturgiczna, na pierwszym planie ks. abp Wojtyła, z lewej biskup lubelski Piotr Kałwa, za nim ks. kardynał Stefan Wyszyński; fot. 3: ks. abp Wojtyła pogrążony w modlitwie w trakcie nabożeństwa na dziedzińcu KUL. 
czy też seria ukazująca składanie przez społeczność KUL życzeń ks. arcybiskupowi z okazji nominacji kardynalskiej, z dnia 13 VI 1967 r. ${ }^{11}$ :
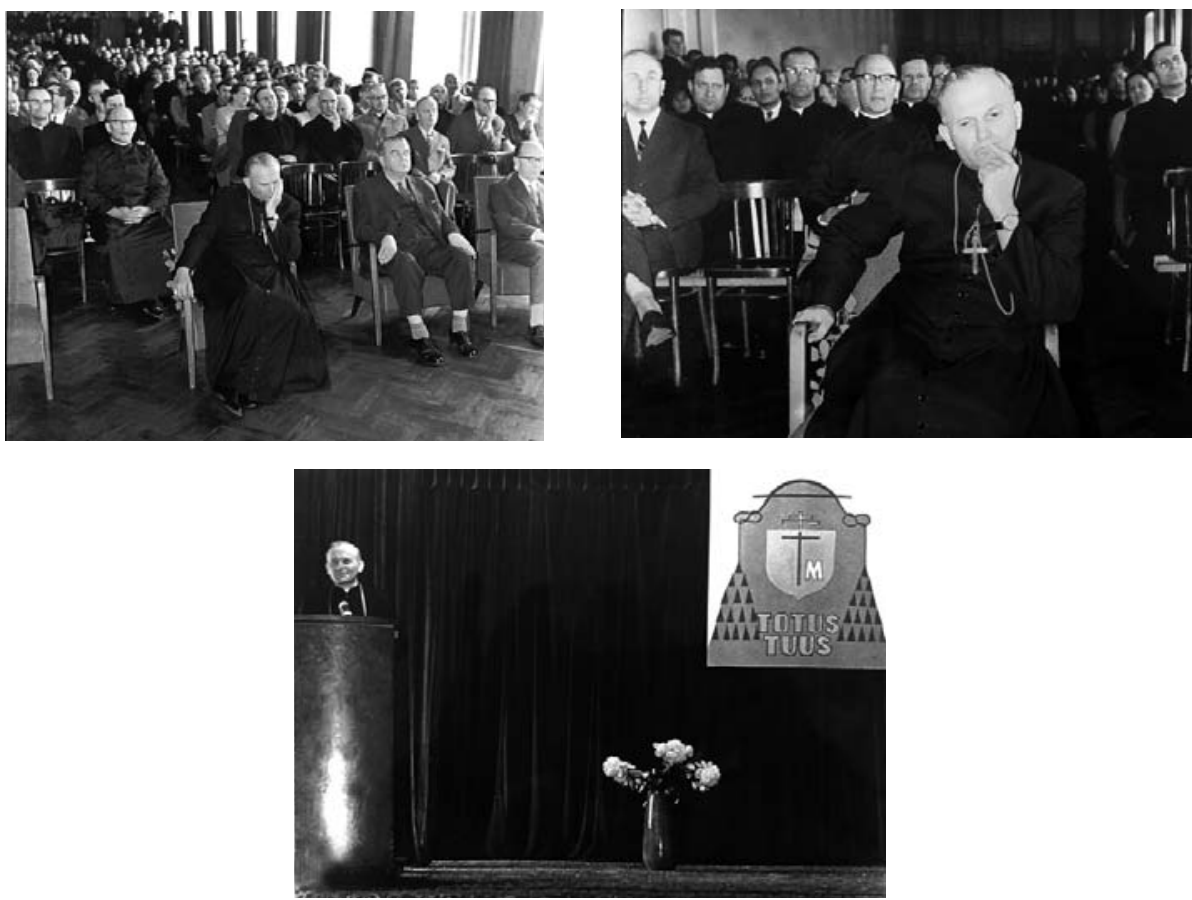

Do innych ciekawych serii fotografii z mniej formalnych spotkań ks. kardynała Wojtyły należą te wykonane w budynkach lub na terenie uniwersytetu, jak np. w rozmowie z ks. Styczniem (fotografia z 13 VI 1967 r.) ${ }^{12}$ :

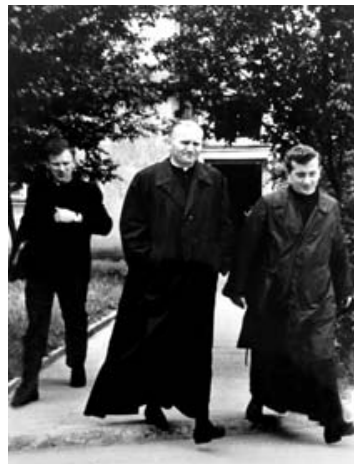

${ }^{11}$ Archiwum..., Zbiór fotografii, seria Karol Wojtyła na KUL - społeczność akademicka składa życzenia Ks. Abpowi z racji nominacji kardynalskiej, 13 VI 1967 r., fot. M. Hałasa. Fotografie wykonane w tzw. Małej Auli.

${ }^{12}$ Archiwum..., Zbiór fotografii, seria Karol Wojtyła na KUL - w rozmowie z ks. Tadeuszem Styczniem, 13 VI 1967 r., fot. M. Hałasa. Fotografia wykonana przed wejściem do Konwiktu Księży Profesorów i Studentów KUL. 
w rozmowie z prof. Leokadią Małunowiczówną (z sierpnia 1972 r.) ${ }^{13}$ :

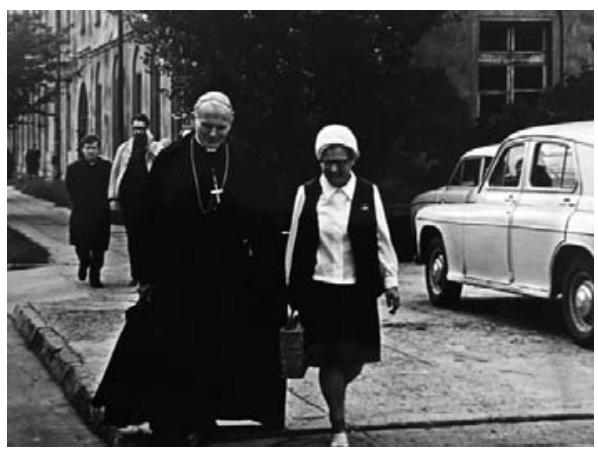

czy też podczas spaceru na dziedzińcu KUL w otoczeniu współpracowników (z lipca lub sierpnia 1972 r.) ${ }^{14}$ :

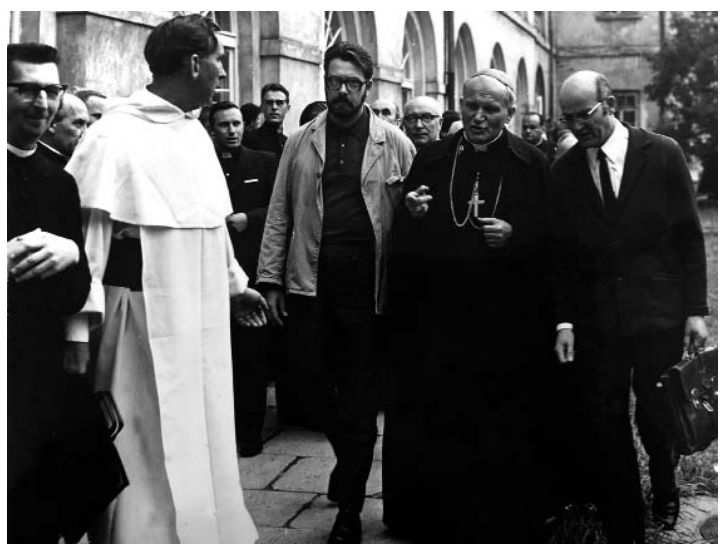

Niektóre z fotografii znajdujących się w wyżej wymienionych seriach są stosunkowo dobrze znane na uniwersytecie. Ich kopie wykonane w wersji wielkoformatowej zdobią np. salę $208 \mathrm{w}$ gmachu głównym KUL (sala, w której wykładał K. Wojtyła, obecnie sala posiedzeń Senatu KUL). Konieczne jest zatem ustalenie ich proweniencji w spuściźnie ks. Stycznia. Być może te same kopie pozytywowe przechowywane są np. w Archiwum Uniwersyteckim. Możliwe, że w trakcie kwerendy odnalezione zostaną wersje pierwotne w postaci negatywów, zwłaszcza że autorem zdecydowanej większości tych najwcześniejszych ujęć był ówczesny fotograf uniwersytecki Marian Hałasa.

${ }^{13}$ Archiwum..., Zbiór fotografii, seria Karol Wojtyła na KUL - w rozmowie z prof. Leokadią Małunowiczówną, sierpień 1972 r., fot. M. Hałasa. Fotografia wykonana na placu przed Kościołem Akademickim. Na drugim planie uczniowie Kardynała, Tadeusz Styczeń i Jerzy Gałkowski.

${ }^{14}$ Archiwum..., Zbiór fotografii, seria Karol Wojtyła na KUL - w otoczeniu pracowników KUL, lipiec lub sierpień 1972 r., fot. M. Hałasa. Na pierwszym planie z lewej w białym habicie rektor, o. Mieczysław Krąpiec, a następnie Jerzy Gałkowski. Z prawej Jerzy Strojnowski. 
W serii fotografii dotyczących $\mathrm{K}$. Wojtyły zachowały się również takie, które wykonywali inni autorzy. Do wyjątkowych wypada zaliczyć np. prywatne fotografie z wyprawy w Tatry w lutym 1974 r., wykonane przez Marię Filipiak ${ }^{15}$ :

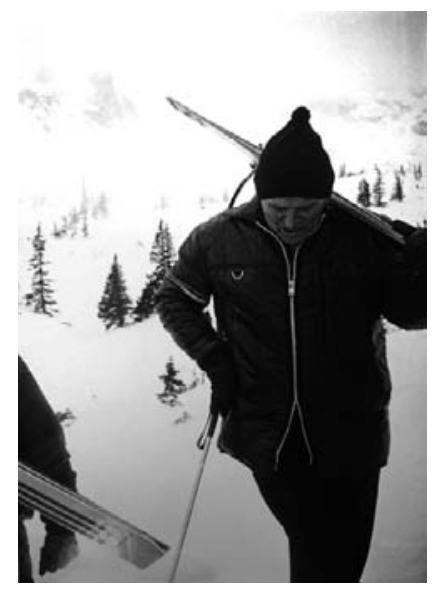

Oczywiście znacznie więcej fotografii K. Wojtyły jest już z czasów jego papieskiego pontyfikatu. Wymienić w tym miejscu można serie odbitek ukazujących udział przedstawicieli KUL w inauguracji pontyfikatu w Rzymie w dniu 22 X 1978 r. (autorstwa m.in. kolejnego uniwersyteckiego fotografa, Janusza Kolasy) ${ }^{16}$ :
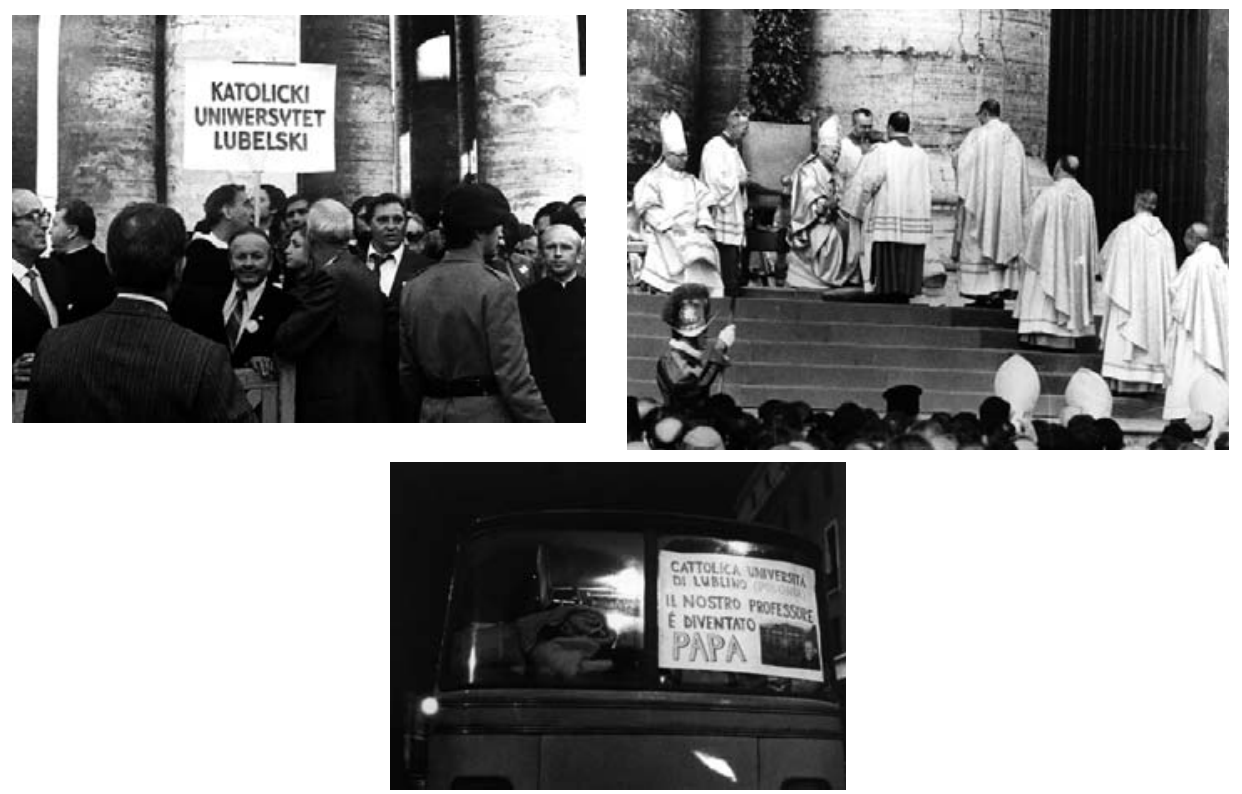

${ }^{15}$ Archiwum..., Zbiór fotografii, seria Karol Wojtyła na nartach w Tatrach, luty 1974 r., fot. M. Filipiak.

${ }^{16}$ Archiwum..., Zbiór fotografii, seria Jan Paweł II - przedstawiciele KUL na inauguracji pontyfikatu, 22 X 1978 r., fot. J. Kolasa. 
Kolejna seria obrazuje spotkanie Jana Pawła II ze społecznością KUL na Jasnej Górze podczas pierwszej pielgrzymki do ojczyzny w dniu 6 VI 1979 r. (autorstwa J. Kolasy i innych fotografów) ${ }^{17}$ :

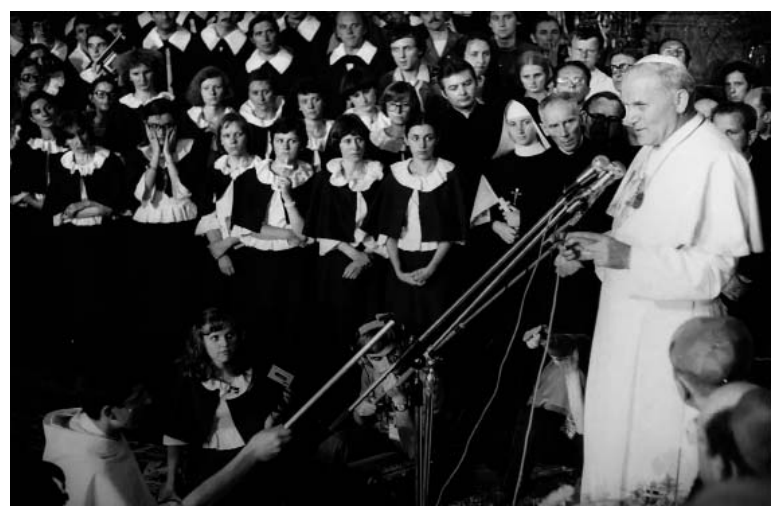

Z kolei dramatyczne dni po zamachu na życie papieża ukazują fotografie przedstawiające msze św. w Kościele Akademickim KUL oraz na uniwersyteckim dziedzińcu ${ }^{18}$ :
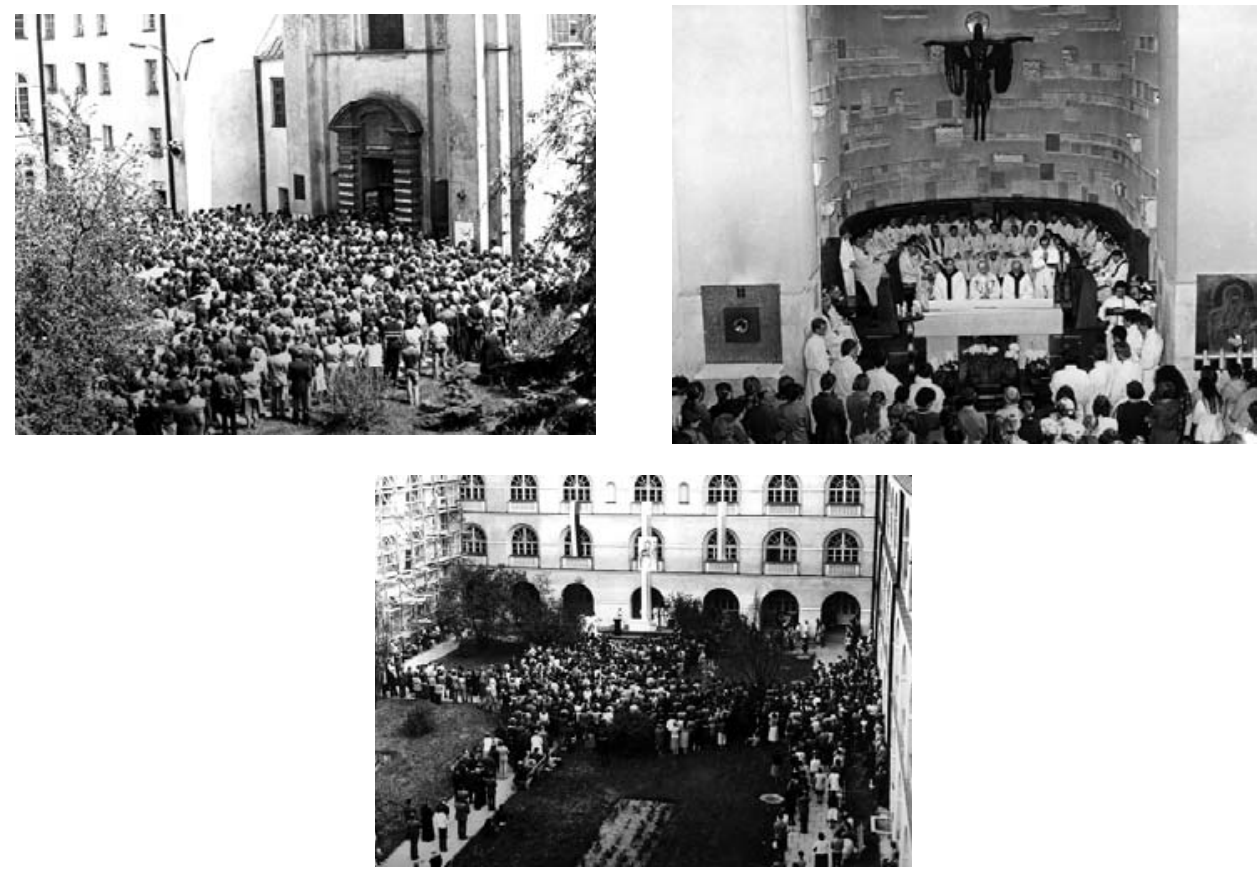

${ }^{17}$ Archiwum..., Zbiór fotografii, seria Jan Paweł II - spotkanie ze społecznością KUL na Jasnej Górze, 6 VI 1979 r., fot. J. Kolasa.

${ }^{18}$ Archiwum..., Zbiór fotografii, seria Jan Paweł II - wydarzenia po zamachu na Jana Pawła II, 1981 r., fot. J. Kolasa. Dwie pierwsze fotografie są z 14 V 1981 r. i przedstawiają mszę św. w Kościele Akademickim KUL, trzecia obrazuje mszę na dziedzińcu uniwersytetu, odprawioną 15 maja. 
W przypadku omówionych wyżej kilku serii fotografii konieczne jest sprawdzenie, czy w spuściźnie są obiekty mające swoje odpowiedniki lub nawet wersje pierwotne w Archiwum Uniwersyteckim KUL.

Wiele fotografii związanych z Janem Pawłem II, początkowo jeszcze czarno -białych, a potem także kolorowych, pochodzi z czasów późniejszych. Dotyczą np. pielgrzymek papieskich do Polski, audiencji pracowników KUL w Rzymie, spotkań naukowych z pracownikami Instytutu Jana Pawła II w Castel Gandolfo. Do ciekawszych należą bez wątpienia prywatne fotografie ukazujące bliską relację ks. Stycznia z Janem Pawłem II i obrazujące mniej formalne wizyty u następcy św. Piotra, jak np. spotkania wigilijno-opłatkowe, autorstwa watykańskiego fotografa Arturo Mari ${ }^{19}$ :
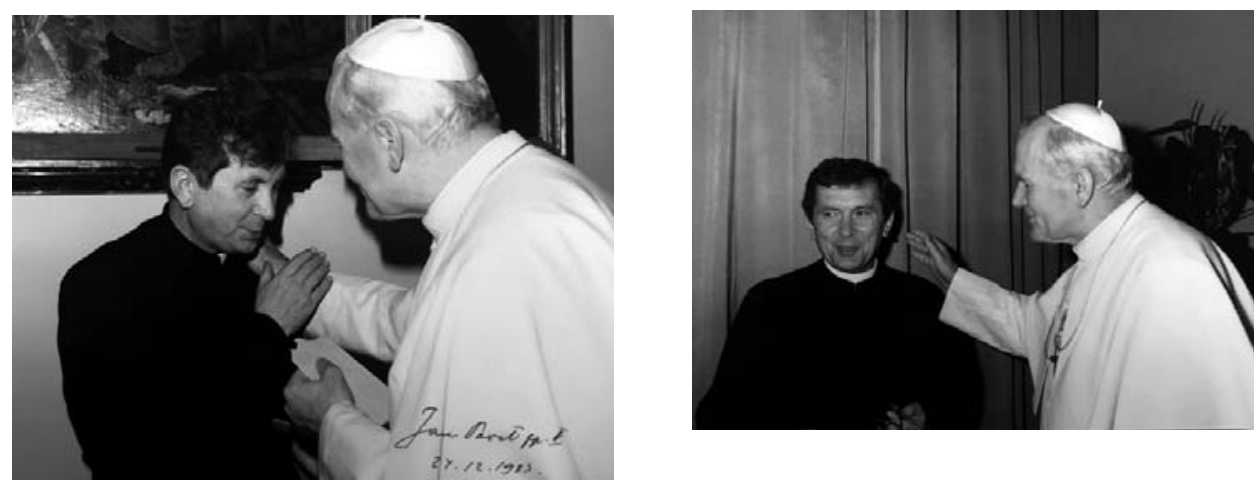

Do ciekawszej kolekcji należy na pewno seria odbitek pozytywowych z różnych lat z wakacji z Ojcem św. we włoskich Alpach (także autorstwa watykańskich fotografów) ${ }^{20}$ :
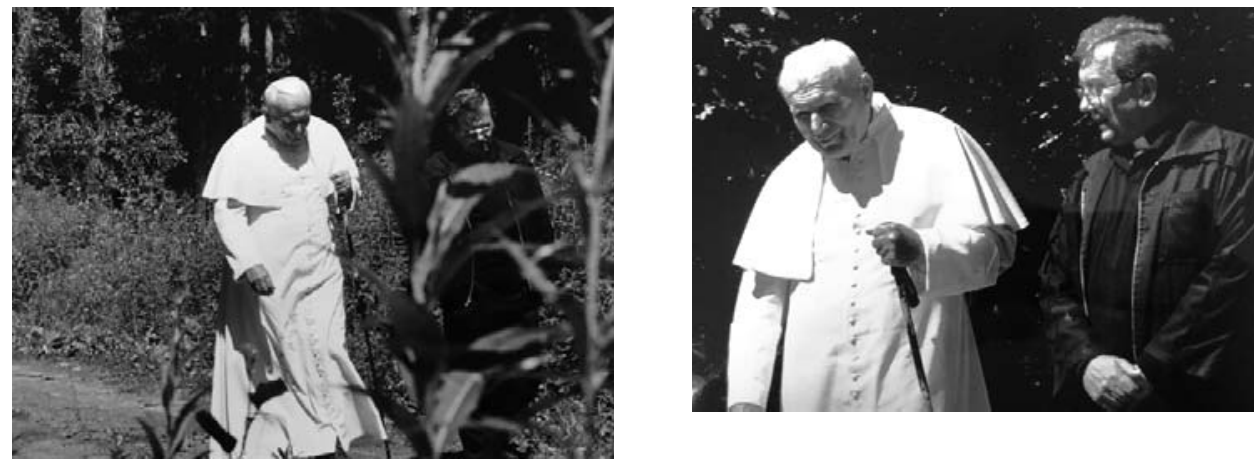

${ }^{19}$ Archiwum..., Zbiór fotografii, seria Jan Paweł II - spotkania wigilijno-opłatkowe z Ojcem św., 1982, 1983, 1985, fot. A. Mari. Jedna z fotografii z autografem Ojca św. i z datą 24 XII $1983 \mathrm{r}$.

${ }^{20}$ Archiwum..., Zbiór fotografii, seria Jan Paweł II - wakacje z Ojcem św., 1992-2002, autorzy różni. 

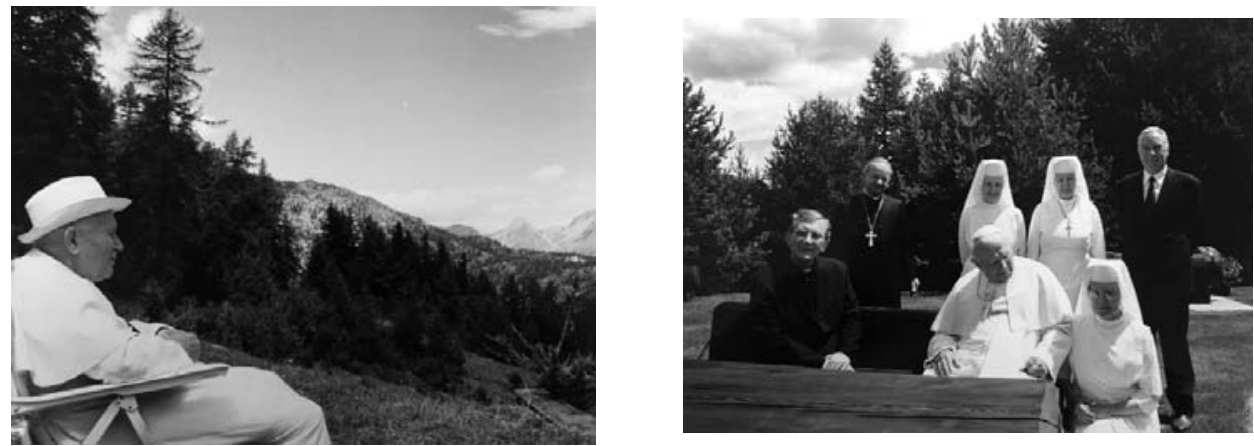

W tej serii jest też jedna szczególna fotografia wykonana na tle włoskich Alp, najbardziej ulubiona przez ks. T. Stycznia:

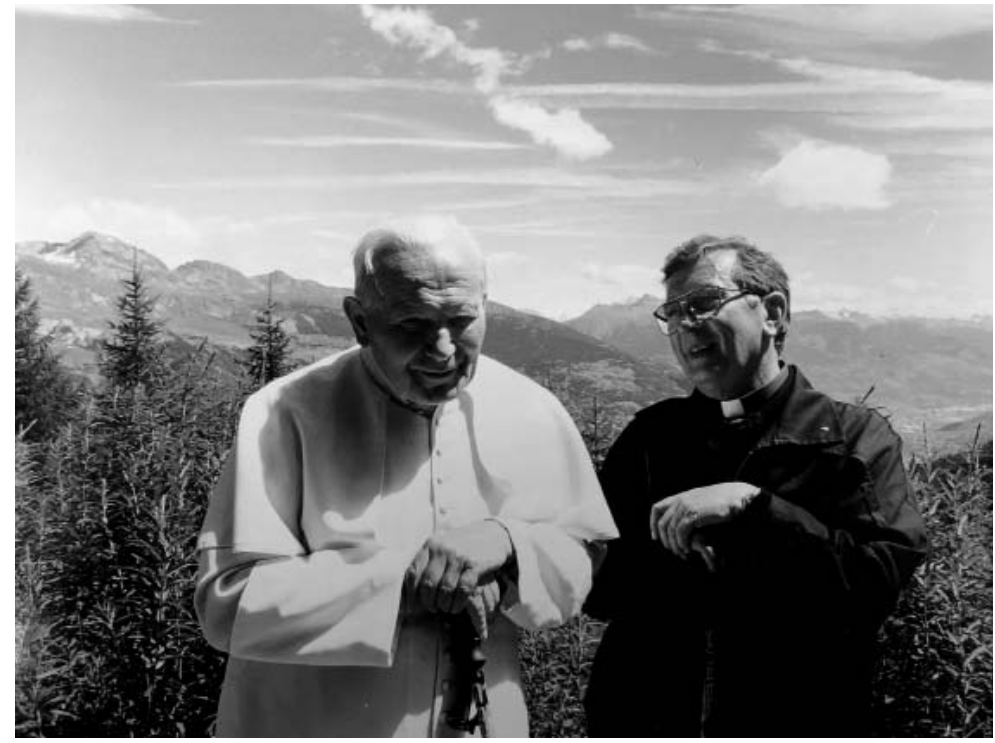

Do innych wyodrębnionych serii należą np. fotografie z uroczystości ogólnouniwersyteckich, jak np. nadania tytułu doktora honoris causa KUL (np. kard. Joachimowi Meissnerowi, kard. Camillo Ruiniemu czy prof. Rocco Butiglione), fotografie $z$ wielu różnych konferencji, sympozjów, kongresów czy sesji naukowych, które były organizowane przez Instytut Jana Pawła II. Wiele zdjęć dotyczy działalności tego Instytutu, tj. prywatnych spotkań pracowników, oficjalnych zebrań naukowych, wizyt i wykładów zaproszonych gości. Pokaźna grupa fotografii ukazuje różnego rodzaju uroczystości jubileuszowe. Zwraca uwagę liczącą niemal 100 ujęć w postaci pozytywowych kopii uroczystość 50-lecia jubileuszu kapłaństwa ks. Stycznia - wydarzenia mającego miejsce w KUL w dniu 5 IV 2005 r., zatem trzy dni po śmierci Jana Pawła II. Na obecnym etapie porządkowania moż- 
na stwierdzić, że tego typu obiektów fotograficznych w zbiorze ks. Stycznia jest najwięcej. Autorami tych nowszych serii, zwłaszcza dotyczących oficjalnych spotkań, sympozjów i kongresów, byli przede wszystkim uczelniani fotografowie: wspomniany już wcześniej Janusz Kolasa, a także Remigiusz Lis i Ireneusz Marciszuk.

Nie oznacza to bynajmniej, że nie spotyka się w spuściźnie pozostawionej przez ks. T. Stycznia fotografii bardziej osobistych czy wręcz rodzinnych, ukazujących jego prywatne relacje i przyjaźnie. Jest ich jednak zdecydowanie mniej niż tych ukazujących działalność akademicką, zwłaszcza w ramach Instytutu, którego był twórcą i którym kierował przez 25 lat. Do grupy ujęć, które obrazują to raczej niezawodowe życie twórcy spuścizny, można w tej chwili zaliczyć przykładowo fotografie ks. T. Stycznia z konwiktu księży, z Ośrodka Wypoczynkowego Księży Salezjanów w Nałęczowie czy z dziedzińca KUL. Są też fotografie nadsyłane przez byłych studentów i przyjaciół ks. T. Stycznia. W pozostałej, jeszcze nie przejrzanej dokładnie części materiałów fotograficznych, będzie więcej tego typu ujęć. Jedno jest pewne - przejrzenie całości zgromadzonych pozytywów, ale także negatywów i slajdów, pozwoli gruntownie i szczegółowo zapoznać się z zawartością zbioru fotografii ks. T. Stycznia.

\section{Podsumowanie}

Przejście etapu porządkowania wstępnego umożliwi podjęcie kolejnych czynności porządkujących, przede wszystkim związanych z klasyfikacją i systematyzacją, a zatem $\mathrm{z}$ wyodrębnieniem ewentualnych podserii i jednostek archiwalnych oraz nadaniem im stosownej, najbardziej praktycznej i użytecznej kolejności. I wreszcie na końcu będzie musiała zostać podjęta próba szczegółowego opisania każdej serii, jednostki, a nawet każdej fotografii. Zapewne pozwoli to znaleźć ewentualne błędy, poprawić pomyłki, wyjaśnić wątpliwości i ostatecznie bardziej dokładnie przypisać fotografie do serii czy podserii. Jednocześnie pozwoli później na dokładne zindeksowanie całości fotograficznej spuścizny ks. T. Stycznia. Nie będzie to jednak możliwe bez udziału osób, które dobrze znały twórcę spuścizny, które z nim współpracowały, żyjących jeszcze jego przyjaciół i zakonnych współbraci. To będzie zapewne etap najtrudniejszy i najbardziej czasochłonny. Bez wątpienia jednak z racji mijającego czasu, kiedy teraźniejszość coraz bardziej oddala się od utrwalonych w fotografiach chwil, warto podjąć się trudu opracowania fotograficznej spuścizny ks. Tadeusza Stycznia.

\section{REFERENCES / BIBLIOGRAFIA}

\section{Źródła}

Archiwum Instytutu Jana Pawła II KUL, Spuścizna archiwalna Księdza Profesora Tadeusza Stycznia SDS

Część aktowa (wg kolejności sygnatur)

Korespondencja: Liechtenstein - rodzina książęca, sygn. 452.

Ochrona życia poczętego, cz. 3, sygn.400/3. 
Korespondencja: Paczkowie Renata i Józef - Pieper Josef, sygn. 457.

Korespondencja: V-W, sygn. 465.

Korespondencja: Watykan, cz. 1, sygn. 466/1.

Korespondencja: Watykan, cz. 2, sygn. 466/2.

Zbiór fotografii (serie wg układu alfabetycznego)

Seria: Jan Paweł II - przedstawiciele KUL na inauguracji pontyfikatu, 22 X 1978 r, fot. J. Kolasa.

Seria: Jan Paweł II - spotkania wigilijno-opłatkowe z Ojcem św., 1982, 1983, 1985, fot. A. Mari.

Seria: Jan Paweł II - spotkanie ze społecznością KUL na Jasnej Górze, 6 VI 1979 r., fot. J. Kolasa.

Seria: Jan Paweł II - wakacje z Ojcem św., 1992-2002, autorzy różni.

Seria: Jan Paweł II - wydarzenia po zamachu na Jana Pawła II, 1981 r., fot. J. Kolasa.

Seria: Karol Wojtyła na KUL - społeczność akademicka składa życzenia Ks. Abpowi z racji nominacji kardynalskiej, 13 VI 1967 r., fot. M. Hałasa.

Seria: Karol Wojtyła na KUL - uroczystości milenijne na KUL, 5-6 VI 1966 r., fot. M. Hałasa.

Seria Karol Wojtyła na KUL - w otoczeniu pracowników KUL, lipiec lub sierpień 1972 r., fot. M. Hałasa.

Seria: Karol Wojtyła na KUL - w rozmowie z ks. Tadeuszem Styczniem, 13 VI 1967 r., fot. M. Hałasa.

Seria Karol Wojtyła na KUL - w rozmowie z prof. Leokadią Małunowiczówną, sierpień 1972 r., fot. M. Hałasa.

Seria: Karol Wojtyła na KUL - wykłady dla duchowieństwa, sierpień 1964 r., fot. M. Hałasa.

Seria: Karol Wojtyła na nartach w Tatrach, II 1974 r., fot. M. Filipiak.

\section{Opracowania}

Chudy Wojciech, Ksiądz Tadeusz Styczeń - ambasador republiki sumienia, „Ethos”, 15 (2002) z. 1-2, s. 297-303.

Jacko Jan Franciszek, Rozmowa z profesorem Josefem Seifertem, rektorem Międzynarodowej Akademii Filozofii w Księstwie Liechtenstein, „Roczniki Filozoficzne”, 43-44 (1996) nr 2, s. 229-233.

Moń Ryszard, Tondel Sylwia, Krokos Jan, Waleszczyński Andrzej, Tadeusz Styczeń, Kraków 2019.

Metodyka pracy archiwalnej, red. S. Nawrocki, S. Sierpowski, Poznań 1998, wyd. 3 zmienione i poszerzone.

Nowicki Tomasz, Misiura Grzegorz, Spuścizna archiwalna Księdza Profesora Tadeusza Stycznia SDS - inwentarz, cz. 1: Dokumentacja aktowa, Lublin 2021.

Nowicki Tomasz, Misiura Grzegorz, Perzyna Krzysztof, Spuścizna archiwalna po Ks. Profesorze Tadeuszu Styczniu SDS (1932-2010) jako przykład archiwum prywatnego po wybitnym uczonym, „Archiva Ecclesiastica”, 10 (2017) s. 13-23.

Podrez Ewa, Ksiądz Tadeusz Styczeń, w: Człowiek, byt, wartość. Antropologiczne i metafizyczne podstawy aksjologii chrześcijańskiej, Warszawa 1989, s. 48-59.

Robótka Halina, Opracowanie i opis archiwaliów, Toruń 2010.

Szostek Andrzej, Styczeń Tadeusz, w: Powszechna encyklopedia filozofii, t. 10, red. nauk. A. Maryniarczyk, Lublin 2009, s. 408-411.

Szostek Andrzej, Styczeń Tadeusz SDS, w: Encyklopedia 100-lecia KUL, t. 2, red. E. Gigilewicz, Lublin 2018, s. 411-412. 
Ślipko Tadeusz, Ksiadz Tadeusz Styczeń, w: Polska filozofia powojenna, Warszawa 2001, s. $257-272$.

Tarsa Monika, Czas - pamięć - fotografia. Próba fenomenologicznej refleksji nad fotografia, „Estetyka i Krytyka”, 7/8 (2/2004-1/2005) s. 164-175.

\title{
Netografia
}

Akty normatywne Naczelnego Dyrektora Archiwów Państwowych, rok 2006, https:// www.archiwa.gov.pl/pl/zarzadzanie-dokumentacja/prawo-archiwalne/akty-normatywne-naczelnego-dyrektora-archiw\%C3\%B3w-pa\%C5\%84stwowych\# (dostęp: 28.10. 2021)

\section{PHOTOGRAPHIC LEGACY OF REV. TADEUSZ STYCZEŃ SDS IN THE ARCHIVES OF JOHN PAUL II INSTITUTE - THE STATE OF ARRANGEMENT}

\begin{abstract}
The Archives of the John Paul II Institute contains the archival legacy of Rev. Pro-fessor Tadeusz Styczeń, Karol Wojtyła's student and long-time director of the John Paul II Institute. The legacy material, apart from the textual documentation already arranged and described, includes numerous items in various forms of photographic image recording. Positive prints constitute the most numerous group, but negatives and image documentation digitally recorded are also held in the archives under study. The author discusses the state of arrangement of this collection from the point of view of archival methodology. He presents significant series and photographic themes, focusing on those which contain photographs connected with the activities of Karol Wojtyła (later Pope John Paul II) at the Catholic University of Lublin. He draws attention to those series of photographic documentation which show a unique relationship between the Pope and the author of the legacy, Rev. Tadeusz Styczeń. In conclusion, he defines the necessary successive stages of archival processing and emphasizes the need for quick arrangement, particularly the description of thematic series as well as the identification of events and people depicted in individual photographs.
\end{abstract}

Keywords: archival legacy; Rev. Tadeusz Styczeń; Institute for Research on the Thought of John Paul II of the Catholic University of Lublin; The John Paul Institute of the Catholic University of Lublin; photograph collections 